\title{
Review \\ Current Use of Equine Laparoscopy in Urogenital Disorders: A Scoping Review of the Literature from 2000 to 2021
}

\author{
Paola Straticò, Giulia Guerri (D), Adriana Palozzo*(D), Vincenzo Varasano and Lucio Petrizzi (D) \\ Veterinary Teaching Hospital, Faculty of Veterinary Medicine, University of Teramo, Località Piano D'Accio, \\ 64100 Teramo, Italy; pstratico@unite.it (P.S.); gguerri@unite.it (G.G.); vvarasano@unite.it (V.V.); \\ lpetrizzi@unite.it (L.P.) \\ * Correspondence: apalozzo@unite.it
}

Citation: Straticò, P.; Guerri, G.; Palozzo, A.; Varasano, V.; Petrizzi, L. Current Use of Equine Laparoscopy in Urogenital Disorders: A Scoping Review of the Literature from 2000 to 2021. Vet. Sci. 2022, 9, 41. https:// doi.org/10.3390/vetsci9020041

Academic Editor: Salvador Ruiz López

Received: 14 December 2021

Accepted: 19 January 2022

Published: 22 January 2022

Publisher's Note: MDPI stays neutral with regard to jurisdictional claims in published maps and institutional affiliations.

Copyright: (C) 2022 by the authors. Licensee MDPI, Basel, Switzerland. This article is an open access article distributed under the terms and conditions of the Creative Commons Attribution (CC BY) license (https:// creativecommons.org/licenses/by/ $4.0 /)$

\begin{abstract}
Background: Laparoscopic surgery replaced traditional invasive techniques for the treatment of common urogenital disorders in equids. The aim of this review is to evaluate applications and the development of urogenital laparoscopy from 2001 to 2021. (2) Methods: A scoping review of literature was undertaken according to the Preferred Reporting Items for Systematic Reviews and Meta-Analysis (PRISMA) guidelines for scoping reviews on three databases (NCBI-PubMed, Web of Science-Thompson Reuters, and SciVerse Scopus). (3) Results: A total of 452 papers were identified. After duplicate removal and title screening, 181 papers underwent abstract screening. Of these, $160+10$ papers (cited by others) were assessed for eligibility according to the PICOs. A total of 132 papers were considered eligible. Most of the research was focused on ovaries and testes, followed by urinary bladder and general articles about laparoscopy in horses. We identified 43 original studies (33\%, RCT, NoRCT, and experimental trials), 39 case series/retrospective studies ( $29 \%), 37$ case reports (28\%), and 13 reviews (10\%, narrative or systematic). (4) Conclusions: Gonadal disorders were the most investigated. Hand-Assisted Laparoscopic Surgery (HALS) and laparoscopic-assisted surgery represent valuable options for more challenging conditions (uterine and urinary bladder disorders).
\end{abstract}

Keywords: laparoscopy; urogenital disorders; surgery; horse; mule; donkey

\section{Introduction}

Urogenital disorders in equids occur due to a variety of conditions of different organs. Abdominal urinary pathologies are mainly represented by urolithiasis $[1,2]$ and bladder neoplasia [3-8], whereas genital disorders are usually related to testes retention [9-12], ovarian neoplasia [13], or unwanted behavior in the mares [14]. Little research has involved uterine conditions mainly for resolution of uterine tears, neoplasia, or infections [15].

Until laparoscopy was first introduced in equine surgery in 1986, the approaches to the aforementioned disorders were typically laparotomic through median or paramedian accesses [16]. From then on, laparoscopic research has focused on techniques based on new instrumentations, combining open and mini-invasive approaches, different positioning of the horse, protocols for standing sedation, methods used to provide hemostasis, and different position, and number of the portals.

Laparoscopy has well-known advantages over laparotomy: an excellent visualization of the abdominal cavity, better assessment of hemostasis, smaller body wall incisions, and secondary reduced risks of wound infection, associated with faster recovery. Moreover, the possibility to avoid general anesthesia, together with its related risk and costs, makes laparoscopy the best surgical option in many conditions. On the other hand, the availability of the instrumentation, the cost related to its maintenance, and the surgeon's familiarity with the technique limits its use. As a rule, the decision for laparoscopy relies on equipment availability, the type of disorder, the patient's characteristics, and the surgeon's ability.

Differently from systematic reviews which focus on a specific question, a scoping review has as the main goal to identify and categorize the evidence about a subject [17]. 
Similarly, they follow a systematic approach to study selection, limiting the bias that exists when a narrative review is undertaken, thus providing a transparent and replicable means of describing the literature on a topic.

The aim of this scoping review was to investigate the equine urogenital disorders most treated with laparoscopy from years 2001 to 2021 and how the research in this field was conducted in the last 20 years.

\section{Materials and Methods}

This scoping review was conducted according to the Preferred Reporting Items for Systematic Reviews and Meta-Analysis (PRISMA) guidelines for scoping reviews [18]. The PRISMA checklist containing information relevant to this scoping review is reported in Appendix A.

Three major veterinary databases were used between August and November 2021 to obtain a list of peer-reviewed publications: NCBI-PubMed, Web of Science-Thompson Reuters, and SciVerse Scopus. Additional relevant records were identified through the references of retrieved publications.

To reduce limitations on publications, only language filters for the type of study were applied: only English language peer-reviewed papers published between 2001 and 2021 were considered. All databases were searched using the advanced search function. The last research was conducted on 20 November 2021.

For the NCBI PubMed database the search string was the following:

$(((($ horse) OR (mule)) OR (donkey)))) AND (laparoscopy)) AND (fft[Filter]),,"Full text, from 2001 2021", "(("“"horse s" "“[All Fields] OR "“"horses"“"[MeSH Terms] OR "“"horses" "“[All Fields] OR" "horse"“[All Fields] OR ("“"equidae"“" [MeSH Terms] OR "“"equidae”"“[All Fields] OR "“"mule" "“[All"“"donkey"“"[All Fields] OR "“"donkeys"“"[All Fields])) AND ("“"laparoscopy" "[All Fields] OR "“laparoscopy"“"[MeSH Terms] OR “"laparoscopy”" [All Fields] OR "“laparoscopies"“"[All Fields]) AND "“loattrfull text"“[Filter]) AND ((fft[Filter]) AND (2001:2021[pdat]))",186,05:41:02.

For the Web of Science database, the search string was the following:

laparoscopy (All Fields) and horse (All Fields) and 2001-2021 (Year Published) not gastrointestinal (All Fields)

For the SciVerse Scopus database the search was the following:

laparoscopy AND horse AND urogenital AND (EXCLUDE (PUBYEAR, 2000 OR EXCLUDE (PUBYEAR, 1999) OR EXCLUDE (PUBYEAR, 1998) OR EXCLUDE (PUBYEAR, 1997) OR EXCLUDE (PUBYEAR, 1996) OR EXCLUDE (PUBYEAR, 1988)) AND (LIMIT-TO (DOCTYPE, “ar") OR LIMIT-TO (DOCTYPE, “re”)) AND (LIMIT TO (SUBJAREA, “VETE”)) AND (LIMIT-TO (LANGUAGE, "English")) AND (LIMIT-TO (SRCTYPE, “j”))

laparoscopy AND donkey AND urogenital AND (LIMIT-TO (DOCTYPE, “ar")) AND (LIMIT-TO (SUBJAREA, “VETE")) AND (LIMIT-TO (LANGUAGE, “English")) AND (LIMIT-TO (SRCTYPE, “j”))

laparoscopy AND mule AND urogenital AND (LIMIT-TO (SUBJAREA, “VETE")) AND (LIMIT-TO (LANGUAGE, “English”)) AND (LIMIT-TO (SRCTYPE, “j”))

Editorials, proceedings, meeting abstracts were not included.

All merged publications were imported into Mendeley reference management and social citation sharing software. Duplicates were removed using the duplicate screening process of the software, and manually when minor differences could not be detected by the software itself. Once duplicates were removed, titles and abstracts were manually screened for relevance.

The first stage of screening was made reviewing only the title and abstract of the paper. If it was unclear whether a citation did or did not meet the inclusion criteria at this step, the paper was included in the second stage of screening, which dealt with full-text screening for eligibility of the included papers. Eligibility was assessed following the objectives modified from "PICOs": Population: horses receiving surgery at the urogenital tract; Intervention: 
laparoscopy; Outcome: postoperative recovery from the disorder. Additionally, reviews about standing urogenital surgery and laparoscopy were included.

Full text papers were accessed from university libraries, library journal subscriptions, and open access sources. Those papers that could not be retrieved and could not undergo the second stage screening were removed.

Categorization of each paper was made on electronic sheets (Microsoft Excel 16.54) and included authors, country of origin, aim of the study, publication type [narrative or systematic reviews, original studies (randomized and non-randomized controlled trials$\mathrm{RCT} /$ NoRCT, experimental studies), case reports, case series/retrospective studies], target organ, and type of surgery.

\section{Results}

\subsection{Selection of Sources of Evidence}

The total number of papers that were retrieved was 452 , which was divided as follows:

- NCBI-PubMed: 186.

- Web of Science-Thompson Reuters: 158.

- $\quad$ SciVerse Scopus: 108.

After removal of duplicates $(n=61)$ and non-applicable titles (human studies, nonequid patients) $(n=210), 181$ abstracts underwent the first stage of screening. Those papers that were not considered eligible according to the PICOs (n. 21), were removed.

A total of 160 papers underwent the second stage of screening considering the full paper version of the studies (Figure 1). During full paper screening, 10 new papers were included for eligibility, as cited by others, for a total number of 170 full papers undergoing eligibility screening. Of these, $38(22 \%)$ were removed because they were not adherent to the PICOs principles. After the second stage of screening, 132 papers were included as eligible (78\%) [19-148].

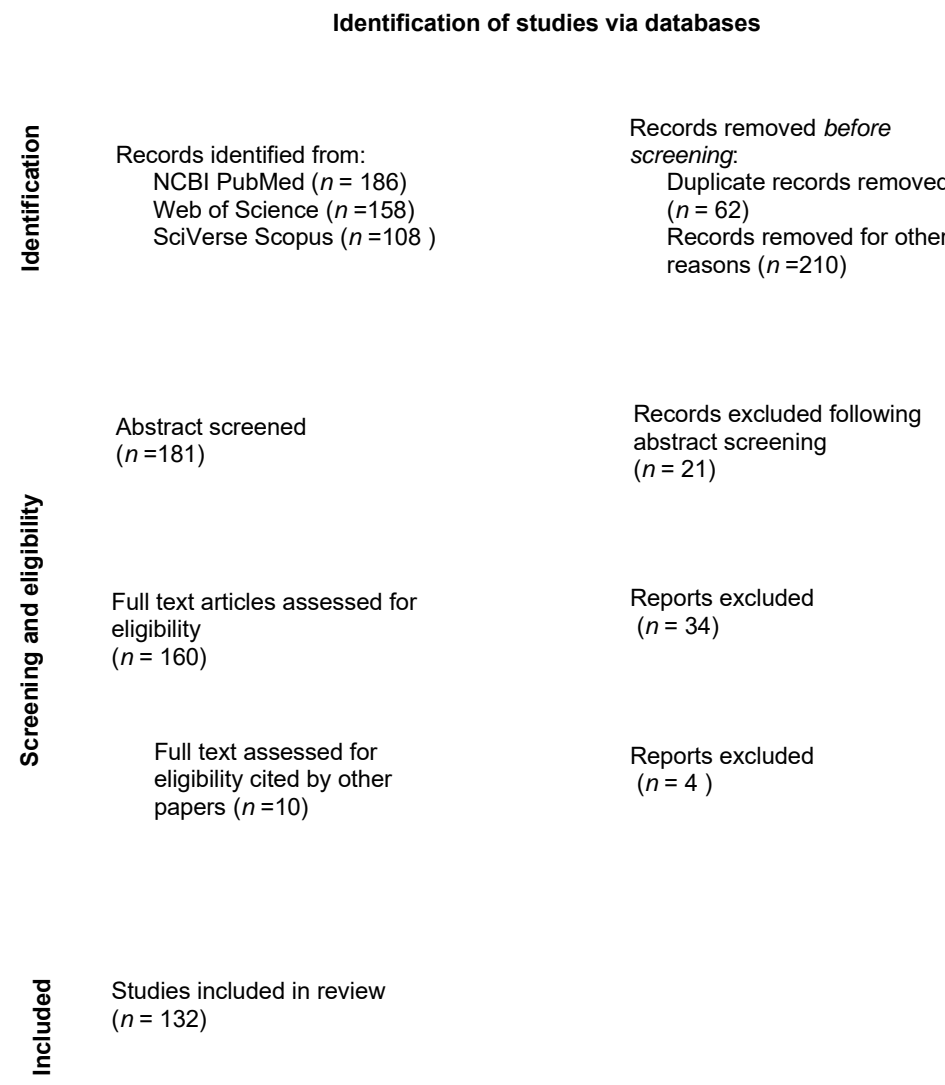

Figure 1. Flow diagram of the search strategy for a scoping review in equine urogenital laparoscopy. Number of publications that were reviewed and excluded during each step of the review process. 


\subsection{Synthesis of Results}

We identified 43/132 original studies, 39/132 case series/retrospective studies, 37/132 case reports, and 13/132 reviews (Table S1) (Figure 2).

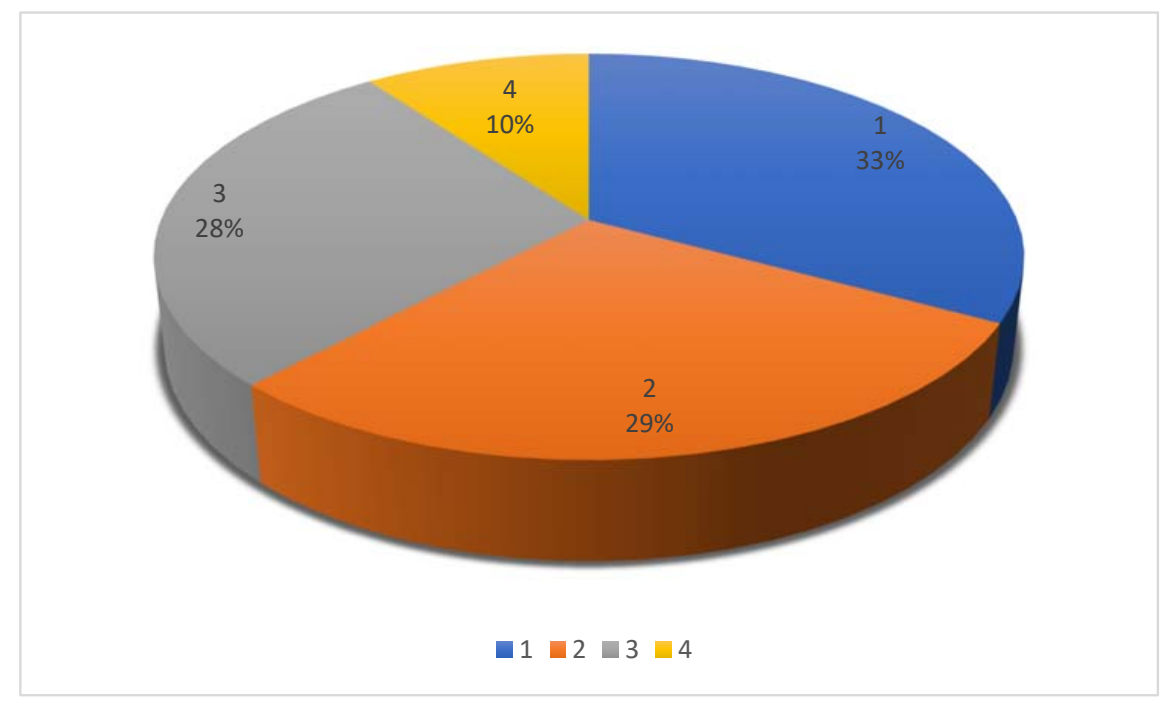

Figure 2. Pie chart showing publication type for 132 citations included in a scoping review (1: original studies 33\%; 2: case series / retrospective studies 29\%, 3: case reports $28 \%$; 4 : reviews $10 \%$ ).

When the target organ was considered, the identified research focused mainly on ovaries $(42 / 132)$ and testes (30/132), followed by urinary bladder (15/132), general information about laparoscopic surgery (11/132), inguinal rings (9/132), uterus (9/132), ovaries- uterus (6/132), kidney (5/132), uterine tubes (4/132), and ductus deferens (1/132) (Figure 3).

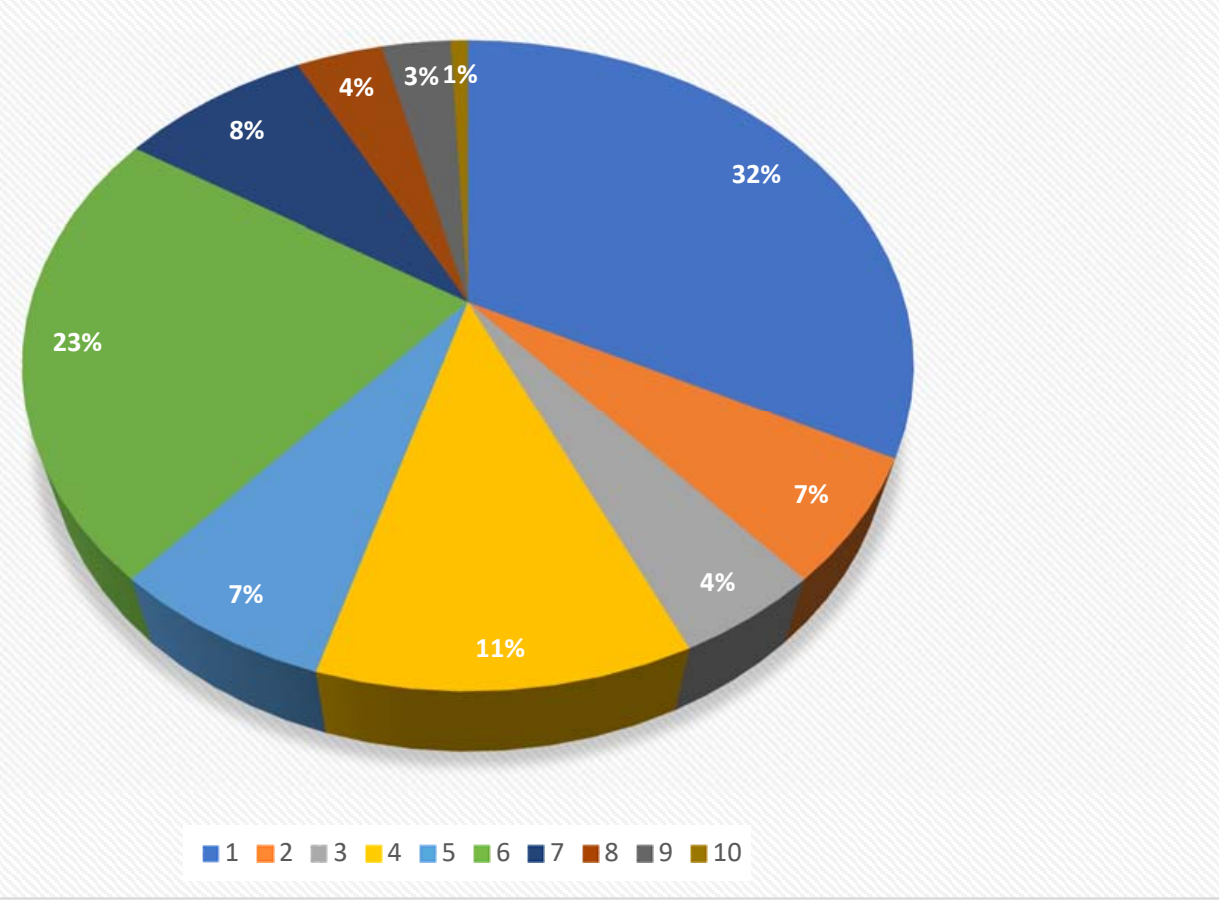

Figure 3. Pie chart showing the distribution of the 132 citations included in a scoping review, categorized according to the target organ/structure (1: ovaries 32\%, 2: uterus $7 \%, 3$ : ovaries-uterus $4 \%$, 4: urinary bladder $11 \%$, 5: inguinal rings $7 \%$, 6: testes $23 \%$, 7 : general information about laparoscopy $8 \%$, 8 : kidney $4 \%$, 9 : uterine tubes $3 \%$, and 10 : ductus deferens $1 \%$ ). 
Organ-related research was distributed as follows (Figure 4):

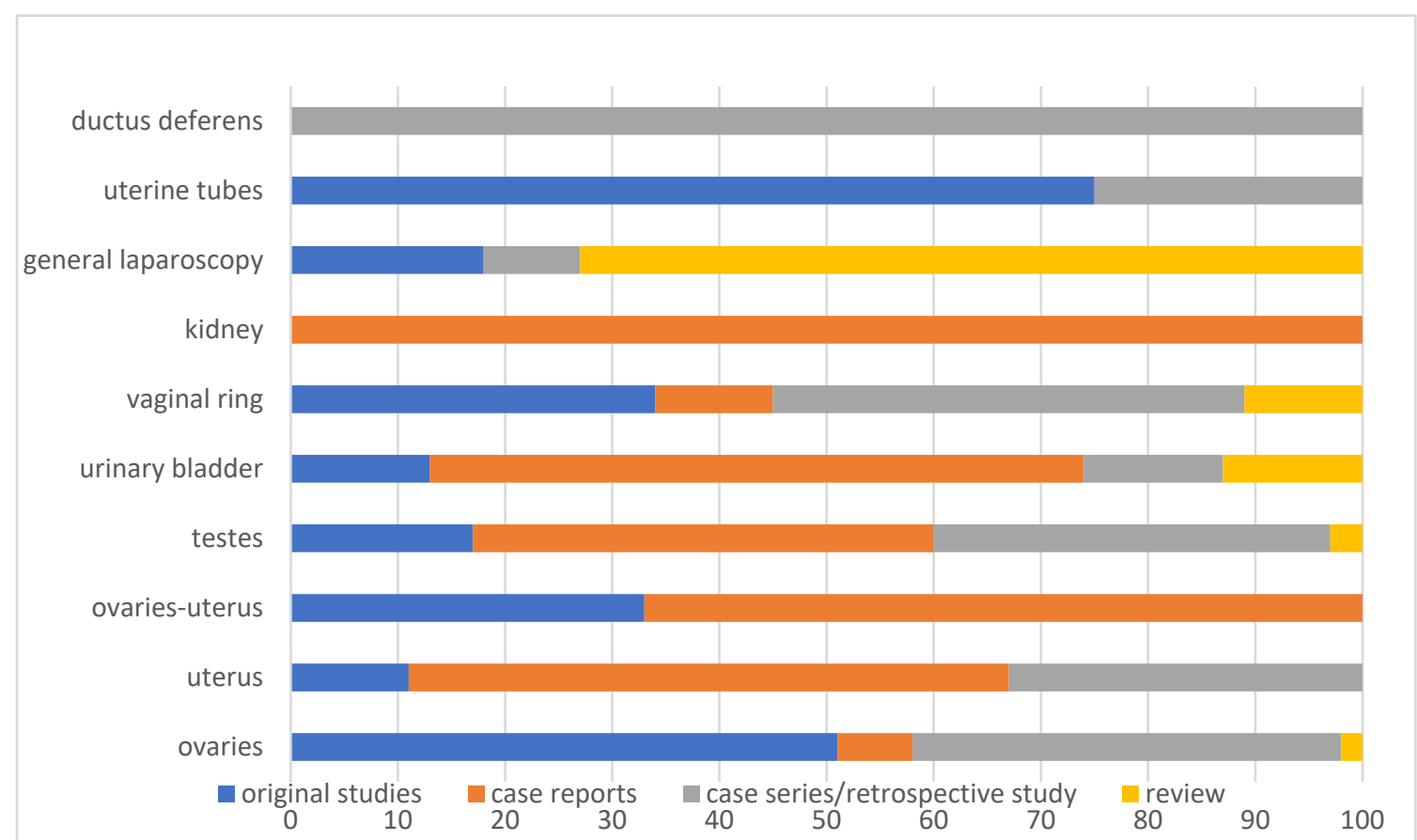

Figure 4. Horizontal bar chart showing the publication type for 132 citations included in a scoping review, categorized according to the target organ/structure and expressed as a percentage (\%).

Ovaries:

$4 / 42(10 \%)$ case reports.

$1 / 42(2 \%)$ review.

$17 / 42(40 \%)$ case series/retrospective studies.

20/42 (48\%) original studies.

Testes:

$5 / 30(17 \%)$ original studies.

$11 / 30(37 \%)$ case series/retrospective studies.

$13 / 30(43 \%)$ case reports.

$1 / 30(3 \%)$ review.

Urinary bladder:

$9 / 15(60 \%)$ case reports.

$2 / 15(13 \%)$ reviews.

$2 / 15(13 \%)$ case series/retrospective studies.

2/15 (13\%) original studies.

General information about laparoscopic surgery

$8 / 11(73 \%)$ reviews.

$1 / 11(9 \%)$ case series/retrospective study.

$2 / 11(18 \%)$ original studies.

Uterus:

$3 / 9(33 \%)$ case series/retrospective studies.

$5 / 9(56 \%)$ case reports.

$1 / 9(11 \%)$ original study.

Inguinal rings:

$3 / 9(33 \%)$ original studies.

$4 / 9(44 \%)$ case series/retrospective studies.

$1 / 9(11 \%)$ case report.

$1 / 9(11 \%)$ review. 
Ovaries and uterus:

$4 / 6(67 \%)$ case reports.

$2 / 6(33 \%)$ original studies.

Kidneys:

$5 / 5(100 \%)$ case reports.

Uterine tubes:

$1 / 4(25 \%)$ case series/retrospective study.

$3 / 4(75 \%)$ original studies.

Ductus deferens:

$1 / 1(100 \%)$ case series.

\section{Discussion}

This scoping review was meant to investigate the equine urogenital disorders that were most treated with laparoscopy from 2001 to 2021 . We also tried to outline the type of studies according to the target organ and/or region.

The use of three main databases allowed a comprehensive search of all the potentially relevant literature: over the last 20 years, it was possible to identify 132 manuscripts that were eligible to be included in this scoping review.

Few reviews in equine laparoscopy were published from 2001 to 2021, mainly represented by narrative reviews about general abdominal surgery [130], the use of laparoscopy $[68,107,129]$, or about standing surgical procedures [19,54,63].

Reviews focused on ovariectomy [67,87], cryptorchidectomy [67,76], management of urolithiasis with reference to laparoscopic approaches $[53,61]$, or standing urogenital surgery [127]. To the authors' knowledge, no scoping review about urogenital laparoscopic surgery has been published before.

A scoping review tries to identify evidence about a subject, rather than evaluate the quality of research. For this reason, the quality assessment tool (QUIPS) developed by Hayden et al. 2013 [149] was not used. Since QUIPS is considered valuable to evaluate the risk of bias and the quality of eligible papers, the lack of these data could be considered a limitation of the study but considering the risk of bias and quality of research went beyond our goals. Moreover, we used a single individual approach to the research, leading to a potential bias of the results.

The most investigated organ was the ovary, with $42 / 132$ of publications (32\%), followed by the testes (30/132, 23\%). Ovariectomy and cryptorchidectomy have always been a challenge in equine surgery due to the limited access and visualization with a laparotomic approach, and to the highest request for surgical intervention. During the last 20 years studies on standing flank laparoscopy, as first described by Fischer et al. [16], have mainly focused on managing a variety of conditions $[29,32,38,40,75,79,85,98,104,111,132,138]$ that were previously treated under general anesthesia and developing new methods for hemostasis $[23,27,33,52,55,64,65,71,72,86,112,116,126,128,131]$. Many publications tried to suggest alternative methods to manage enlarged ovaries [41,83,89] and abdominally retained testes [124] and reduce surgical time, decrease damage to the abdominal wall during extraction and avoid secondary complications related to the incision, as well as reduce the risk of dropping the gonad within the abdominal cavity [41]. On this topic, the use of morcellator is without any doubt the most investigated aspect, although carrying some disadvantages (high costs of the equipment and risk of damage to other organs) $[41,83,89,124]$.

Recently, a single side laparoscopic approach for bilateral laparoscopic ovariectomy has been described [35,49]. Its main advantage is the possibility to enter the abdominal cavity from the same flank through five portals, avoiding bilateral paralumbar incisions. On the other hand, this approach is not suitable for larger mares. Moreover, one of the portals must be localized between the 17th and 18th ribs, with the risk of thoracic cavity penetration [150].

A new approach to the abdominal cavity for treating ovarian disorders is represented by the transvaginal natural orifice transluminal endoscopic surgery $[21,96,97]$ (NOTES). 
This was first introduced in swine [151,152] and then used on animals and people [153-155]. It can be considered a development of abdominal surgery via transvaginal colpotomy that is well known in mares $[133,136,156-158]$. Advantages of NOTES over laparoscopy are mainly represented by the lack of abdominal wounds, but concerns are expressed about the potential transvaginal abdominal contamination and possibility to develop adhesion at the entry site. Moreover, long instruments are mandatory, and the procedure is considered more technically challenging than laparoscopy [21].

Laparoscopic ovariectomy was also used to treat unwanted estrus-related behavior in equids, with conventional approaches and follow-up with the owners to investigate the success of removal on behavior [36,50,100]. Devick et al. (2020) [35] investigated a relationship between owners' satisfaction after bilateral ovariectomy toward complained behavior and endocrinological profiles of the mares. They concluded that no correlation could be found, and that the reason for the complaint must include ovarian neoplasia (early granulosa cell tumors). According to Collar and colleagues no association could be found even between behavior and response to altrenogest in mares [36]. Even if mostly unable to maintain a pregnancy, this aspect was investigated also in mule mare, with similar results [100]. In all cases, client perspective was used to assess behavioral improvement, which could have led to bias.

HALS (Hand-Assisted-Laparoscopic-Surgery) proved to be a valid option in the field of equine laparoscopy as an aid in case of particularly enlarged organs or neoplasia $[26,69,92]$, especially when the size of the mass cannot be reduced intraabdominally $[41,74,102,117,119,142]$. These techniques provide excellent visualization of the abdominal cavity, while the direct manipulation of the target organ with the surgeon's hand allows more efficient maneuvers than instrumental control. Compared to standard laparoscopy, HALS is much easier to learn, thanks to the three-dimensional feedback of one hand into the surgical field that can be used for blunt dissection, as a retractor, or as an aid in providing hemostasis [60].

In the two last decades, novel interest in the field of urogenital laparoscopic surgery is shown in equids different from the horse, mainly for gonadal disorders $[25,99,100]$. Pepe et al. (2005) [99] described the use of an endoscopic linear stapler to transect the spermatic cord under laparoscopic guidance, leading to testicular avascular necrosis in six weeks without testicle removal in asses. Testosterone follow-up was available for 12 months, during which no signs of revascularization were observed (testosterone $<15 \mathrm{ng} / \mathrm{dL}$ ). A custom-made device for isolation, coagulation, and cutting of the mesovarium was described in donkeys [25]. The main advantage of this device was a triple function in one instrument, although a considerable amount of smoke was produced.

Surgery of the urinary bladder $(15 / 132,11 \%)$ can be considered a wide chapter mainly dedicated to the treatment of urolithiasis [88,93,113,134,141], neoplasia [4], and ruptures $[91,95,108,109,123,137]$. Although thorough laparoscopic approaches to the urinary bladder were described [159], many surgeons seem to prefer a combination among laparoscopic and laparotomic techniques, to obtain a better visualization of the urinary bladder under laparoscopic guidance and avoid the need for intracorporeal sutures exteriorizing the organ. Laparoscopy carries the advantage of reducing tension on the wall of the bladder and the avoidance of larger incisions through the abdominal wall with the risk of wound complication or vessel damage $[53,160,161]$. On the other hand, the increased probability of urine contamination within the abdomen and calculi fragmentation into the peritoneal cavity make the technique particularly challenging. For these reasons, in urinary bladder surgery, the choice of the specific technique is based on the patient's gender, surgeon's preference, and urolith diameter.

A valuable aid for the synthesis of the bladder is represented by barbed sutures (mono-or bidirectional), which avoid the need of intracorporeal knots. Although already used in human bladder surgery [162-165], few studies are published in vivo on equine patients $[37,103,166]$. Only ex-vivo studies are reported in equine urogenital disorders [91,123], showing equal efficacy for both types of sutures (mono and bidirectional) during experi- 
mental cystorrhaphies, although the surgeon's confidence with the technique is mandatory to ensure a good result. Since in human studies, these knotless sutures decreased the amount of suture material incorporated into the closure, as well as surgical time, ensuring the same performances, further research in veterinary surgery should be undertaken in vivo.

Uterine disorders $(9 / 132,7 \%)$ considered in literature were neoplasia $[74,94,102]$, tears [26,43,51,92], infections [43,148], and ligament laxity [28,37].

Ovariohysterectomy $(6 / 132,4 \%)$ was also described thorough a laparoscopic approach although laparoscopic-assisted approaches were generally preferred: after laparoscopic hemostasis and resection of mesovarium and mesometrium in the standing mare, surgery continues with an open withdrawal of the uterus in dorsal recumbency under general anesthesia [26,44,46], or a transvaginal approach under sedation [59], or unilateral handassisted removal $[79,148]$. The transvaginal uterine removal is described in a case report (of uterine adenocarcinoma) that was particularly challenging because of the uterine tone. Moreover, the authors suggest uterine lavage prior to surgery, to reduce the risks of abdominal contamination in case of rupture. Since no objective evaluation of post-operative pain was accomplished, no conclusion about the advantages of this technique can be drawn.

Inguinal hernia repair $(9 / 132,7 \%)$ was often attempted and described in stallions with a therapeutic and/or prophylactic purpose, aiming at preserving the testicular vascularization and function. Intracorporeal suture closure of the internal inguinal rings [30], mesh or cyanoacrylate application at the same site [121], and peritoneal flaps [62,103,146,147] are all surgical options that were considered for inguinal hernias. A literature review was published investigating the laparoscopic closure of the inguinal rings in stallions [61]. All these techniques are described in a standing laparoscopic approach. Different intra and post-operative complications were described for all the techniques (bleeding during peritoneal flaps, reherniation, testicular atrophy, hemospermia, and scrotal edema). The authors conclude that for unknown reasons peritoneal flaps are associated with the most severe postoperative complications. Further research is requested to assess the postsurgical testicular function.

Renal disorders amenable to surgical treatment are relatively uncommon in horses. Hand-assisted laparoscopic nephrectomy was described [80] and used for treating unresolved ureteral ectopia in a foal [34], renal disease [114], or neoplasia [69,119]. Compared to laparotomy, laparoscopic nephrectomy avoids general anesthesia and rib resection with good visualization and secure ligation of renal vessels. The hand-assisted technique does not avoid the need for a mini-laparotomy but simplifies the procedure, reduces surgical time, and allows more direct and safer circumferential isolation and mobilization of the kidney [114].

In some reports, assessment, and treatment of oviductal patency in mares under laparoscopic guidance was also faced, with good results (4/132 3\%) [22,24,82,101]. The use of fluorescent beads laid down into the infundibulum under laparoscopic guidance, allowed the evaluation of plugs in the oviducts of mares and the shape of the infundibulum; obstruction of the oviduct and rough shape of the infundibulum are two potential causes of potential infertility [24] that could be addressed, although peritonitis and bowel puncture were described as potential risks. $\mathrm{PGE}_{2}$ was successfully used to restore oviductal patency as a topical gel application over the tube under laparoscopic guidance [22].

Only 1 study out of 132 (1\%) was focused on laparoscopic vasectomy in four stallions with a left laparoscopic flank approach, achieving an adequate azoospermia without interference with the reproductive behavior. The standing procedure was faster and easier than the same performed under general anesthesia, without the need for specialized equipment. Nevertheless, the availability of a vessel sealing device facilitates the surgery [140].

Although we did not include publications focused on the protocols for general anesthesia and sedation, a great interest was shown by authors on this topic [167-172]. Caudal epidural anesthesia with alpha-2 agonist and opioid combined with sedation, was a great support in providing analgesia during standing procedures [71,173-176], reducing surgical 
times and risks related to the patient and to the equipment. Considerations about the animal size must be done, since the drugs given epidurally should reach the emergence of the ovarian nerve plexus at the caudal mesenteric ganglion, ventral to the lumbar spinal vertebra 3 (L3) [177]. Moreover, local anesthetic techniques were investigated to reduce pain during the laparoscopic procedures and to minimize the amount of sedative and anesthetic drugs to be used [81]. Among them, local infiltration of lidocaine in the mesorchium/mesovarium or gonadal parenchyma were compared, with the best results for intramesovaric inoculation rather than intraovarian [57]. Moreover, attention was given to the effects of pneumoperitoneum on physiologic variables [178-180].

Due to the breadth of the literature included and to the different procedures described a comparison among studies was not carried out [131]. Usually, comparisons are impaired because of different definitions of intra- and post-operative complications as defined by the authors and because of the different architecture of the studies designs.

\section{Conclusions}

Laparoscopic urogenital surgery has a variety of applications mostly related to the treatment of gonadal disorders. The development of HALS allowed the diffusion of the mini-invasive approaches also to more challenging conditions, such as uterine and renal pathologies. The urinary bladder is usually approached with laparoscopic-assisted methods, rather than thorough laparoscopic method.

Although the advantages of laparoscopy over laparotomy are well known, the decisionmaking process takes into consideration patients characteristics (size and temperament), equipment availability, clinical condition (mainly the size of the mass to remove), and the surgeon's preference and confidence with mini-invasive techniques.

Nevertheless, in the authors' opinion, a comparison between studies is difficult because of the variety of designs and case reports. More RCT should be designed to compare clinical conditions and treatments.

Supplementary Materials: The following supporting information can be downloaded at: https: / / www.mdpi.com/article/10.3390/vetsci9020041/s1, Table S1: summary of the publications that were included as eligible.

Author Contributions: Conceptualization, P.S., G.G. and L.P.; methodology, P.S., A.P. and G.G.; validation, P.S., G.G., A.P., V.V. and L.P.; formal analysis, G.G., A.P., L.P. and V.V.; investigation, P.S.; resources, V.V. and L.P.; data curation, P.S.; writing-original draft preparation, P.S.; writing-review and editing, G.G., A.P., V.V. and L.P.; visualization, P.S., G.G., A.P., V.V. and L.P.; supervision, L.P. All authors have read and agreed to the published version of the manuscript.

Funding: This research received no external funding.

Conflicts of Interest: The authors declare no conflict of interest.

\section{Appendix A}

Table A1. Preferred Reporting Items for Systematic reviews and Meta-Analyses extension for Scoping Reviews (PRISMA-ScR) Checklist.

\begin{tabular}{cccc}
\hline Section & Item & Prisma-ScR Checklist Item & Reported on Page \\
\hline Title & 1 & Title & 1 \\
\hline Structured summary & 2 & $\begin{array}{c}\text { Pdentify the report as a scoping review. } \\
\text { objectives, eligibility criteria, sources of evidence, charting methods, results, and } \\
\text { conclusions that relate to the review questions and objectives. }\end{array}$ & 1 \\
\hline
\end{tabular}


Table A1. Cont.

\begin{tabular}{ccc}
\hline Section & Item & Prisma-ScR Checklist Item \\
\hline Rationale & 3 & $\begin{array}{c}\text { Describe the rationale for the review in the context of what is already known. } \\
\text { Explain why the review questions/objectives lend themselves to a scoping } \\
\text { review approach. }\end{array}$
\end{tabular}

$$
\text { review approach. }
$$

Provide an explicit statement of the questions and objectives being addressed

Objectives $\quad 4 \quad$ with reference to their key elements (e.g., population or participants, concepts, and context) or other relevant key elements used to conceptualize the review questions and/or objectives.

\begin{tabular}{|c|c|c|c|}
\hline \multicolumn{4}{|c|}{ Methods } \\
\hline Protocol and registration & 5 & $\begin{array}{c}\text { Indicate whether a review protocol exists; state if and where it can be accessed } \\
\text { (e.g., a Web address); and, if available, provide registration information, } \\
\text { including the registration number. }\end{array}$ & n.a. \\
\hline Eligibility criteria & 6 & $\begin{array}{l}\text { Specify characteristics of the sources of evidence used as eligibility criteria (e.g., } \\
\text { years considered, language, and publication status), and provide a rationale. }\end{array}$ & 2 \\
\hline Information sources & 7 & $\begin{array}{c}\text { Describe all information sources in the search (e.g., databases with dates of } \\
\text { coverage and contact with authors to identify additional sources), as well as the } \\
\text { date the most recent search was executed. }\end{array}$ & 2 \\
\hline Search & 8 & $\begin{array}{l}\text { Present the full electronic search strategy for at least one database, including any } \\
\text { limits used, such that it could be repeated. }\end{array}$ & 2 \\
\hline $\begin{array}{l}\text { Selection of sources of } \\
\text { evidence }\end{array}$ & 9 & $\begin{array}{l}\text { State the process for selecting sources of evidence (i.e., screening and eligibility) } \\
\text { included in the scoping review. }\end{array}$ & $2-3$ \\
\hline Data charting process & 10 & $\begin{array}{l}\text { Describe the methods of charting data from the included sources of evidence } \\
\text { (e.g., calibrated forms or forms that have been tested by the team before their } \\
\text { use, and whether data charting was performed independently or in duplicate) } \\
\text { and any processes for obtaining and confirming data from investigators. }\end{array}$ & 3 \\
\hline Data items & 11 & $\begin{array}{l}\text { List and define all variables for which data were sought and any assumptions } \\
\text { and simplifications made. }\end{array}$ & n.a. \\
\hline $\begin{array}{l}\text { Critical appraisal of } \\
\text { individual sources } \\
\text { of evidence }\end{array}$ & 12 & $\begin{array}{l}\text { If completed, provide a rationale for conducting a critical appraisal of included } \\
\text { sources of evidence; describe the methods used and how this information was } \\
\text { used in any data synthesis (if appropriate). }\end{array}$ & n.a. \\
\hline Synthesis of results & 13 & Describe the methods of handling and summarizing the data that were charted. & 3 \\
\hline \multicolumn{4}{|c|}{ Results } \\
\hline $\begin{array}{l}\text { Selection of sources } \\
\text { of evidence }\end{array}$ & 14 & $\begin{array}{l}\text { Give numbers of sources of evidence screened, assessed for eligibility, and } \\
\text { included in the review, with reasons for exclusions at each stage, ideally using a } \\
\text { flow diagram. }\end{array}$ & 3 \\
\hline $\begin{array}{l}\text { Characteristics of sources } \\
\text { of evidence }\end{array}$ & 15 & $\begin{array}{l}\text { For each source of evidence, present characteristics for which data were charted } \\
\text { and provide the citations. }\end{array}$ & n.a. \\
\hline $\begin{array}{l}\text { Critical appraisal within } \\
\text { sources of evidence }\end{array}$ & 16 & $\begin{array}{l}\text { If completed, present data on critical appraisal of included sources of evidence } \\
\text { (see item 12). }\end{array}$ & n.a. \\
\hline $\begin{array}{l}\text { Results of individual } \\
\text { sources of evidence }\end{array}$ & 17 & $\begin{array}{l}\text { For each included source of evidence, present the relevant data that were } \\
\text { charted that relate to the review questions and objectives. }\end{array}$ & Suppl.mat. \\
\hline Synthesis of results & 18 & $\begin{array}{l}\text { Summarize and/or present the charting results as they relate to the review } \\
\text { questions and objectives. }\end{array}$ & Suppl.mat. \\
\hline \multicolumn{4}{|c|}{ Discussion } \\
\hline Summary of evidence & 19 & $\begin{array}{l}\text { Summarize the main results (including an overview of concepts, themes, and } \\
\text { types of evidence available), link to the review questions and objectives, and } \\
\text { consider the relevance to key groups. }\end{array}$ & $8-11$ \\
\hline Limitations & 20 & Discuss the limitations of the scoping review process. & 9 \\
\hline Conclusions & 21 & $\begin{array}{l}\text { Provide a general interpretation of the results with respect to the review } \\
\text { questions and objectives, as well as potential implications and/or next steps. }\end{array}$ & $11-12$ \\
\hline
\end{tabular}

$$
\text { Funding }
$$

Funding

Describe sources of funding for the included sources of evidence, as well as
sources of funding for the scoping review. Describe the role of the funders of the scoping review.

JBI = Joanna Briggs Institute; PRISMA-ScR = Preferred Reporting Items for Systematic reviews and Meta-Analyses extension for Scoping Reviews. 


\section{References}

1. Laverty, S.; Pascoe, J.R.; Ling, G.V.; Lavoie, J.P.; Ruby, A.L. Urolithiasis in 68 horses. Vet. Surg. 1992, 21, 56-62. [CrossRef]

2. Holt, P.E.; Pearson, H. Urolithiasis in the horse: A review of 13 cases. Equine Vet. J. 1984, 16, 31-49. [CrossRef] [PubMed]

3. Cornelisse, C.J. Urinary tract neoplasia. In Current Therapy in Equine Medicine, 5th ed.; Robinson, N.E., Ed.; W.B. Saunders: Philadelphia, PA, USA, 2003; pp. 835-837.

4. Serena, A.; Naranjo, C.; Koch, C.; Darien, B.J. Resection cystoplasty of a squamous cell carcinoma in a mare. Equine Vet. Educ. 2009, 21, 263-266. [CrossRef]

5. Sweeney, R.W.; Hamir, A.N.; Fisher, R.R. Lymphosarcoma with urinary bladder infiltration in a horse. J. Am. Vet. Med. Assoc. 1991, 199, 1177-1178.

6. Fischer, A.T., Jr.; Spier, S.; Carlson, G.P.; Hackett, R.P. Neoplasia of the equine urinary bladder as a cause of hematuria. J. Am. Vet. Med. Assoc. 1985, 186, 1294-1296. [PubMed]

7. Turnquist, S.E.; Pace, L.W.; Keegan, K.; Andrews-Jones, L.; Kreeger, J.M.; Bailey, K.L.; Stogsdill, P.L.; Wilson, H.A. Botryoid rhabdomyosarcoma of the urinary bladder in a filly. J. Vet. Diag. Investig. 1993, 5, 451-453. [CrossRef] [PubMed]

8. Hurcombe, S.D.A.; Slovis, N.M.; Kohn, C.W.; Oglesbee, M. Poorly differentiated leiomyosarcoma of the urogenital tract in a horse J. Am. Vet. Med. Assoc. 2008, 233, 1908-1912. [CrossRef]

9. Davis, E.W. Laparoscopic cryptorchidectomy in standing horses. Vet. Surg. 1997, 26, 326-331. [CrossRef] [PubMed]

10. Hendrickson, D.A.; Wilson, D.G. Laparoscopic cryptorchid castration in standing horses. Vet. Surg. 1997, 26, 335-339. [CrossRef]

11. Fischer, A.T.; Vachon, A.M. Laparoscopic cryptorchidectomy in horses. J. Am. Vet. Med. Assoc. 1992, 201, 1705-1708.

12. Ragle, C.A.; Southwood, L.L.; Howlett, M.R. Ventral abdominal approach for laparoscopic cryptorchidectomy in horses. Vet. Surg. 1998, 27, 138-142. [CrossRef] [PubMed]

13. Wilderjans, H. Ovariectomy for removal of large pathologic ovaries in the mare. In Advances in Equine Laparoscopy; Ragle, C.A., Ed.; Wiley \& Sons, Inc.: Hoboken, NJ, USA, 2012; pp. 189-201.

14. Ragle, C.A. Bilateral ovariectomy in the mare. In Advances in Equine Laparoscopy; Ragle, C.A., Ed.; Wiley \& Sons, Inc.: Hoboken, NJ, USA, 2012; pp. 177-188.

15. Roetting, A.K.; Freeman, D.E. Hysterectomy. In Equine Reproduction, 2nd ed.; Mckinnon, A.O., Squires, E.L., Vaala, W.E., Varner, D.D., Eds.; Wiley-Blackwell Publishing Ltd.: Hoboken, NJ, USA, 2011; pp. 2752-2755.

16. Fischer, A.T.; Lloyd, K.C.; Carlson, G.P.; Madigan, J.E. Diagnostic laparoscopy in the horse. J. Am. Vet. Med. Assoc. 1986, $189,289-292$

17. Arksey, H.; O'Malley, L. Scoping studies: Towards a methodological framework. Int. J. Soc. Res. Methodol. 2005, 8, 19-32. [CrossRef]

18. Tricco, A.C.; Lillie, E.; Zarin, W.; O’Brien, K.K.; Colquhoun, H.; Levac, D.; Moher, D.; Peters, M.D.J.; Horsley, T.; Weeks, L.; et al. PRISMA Extension for scoping reviews (PRISMA-ScR): Checklist and explanation. The PRISMA-ScR Statement. Ann. Intern. Med. 2018, 169, 467-473. [CrossRef]

19. Adams, A.; Hendrickson, D.A. Standing male urogenital surgery. Vet. Clin. N. Am. 2014, 30, 169-190.

20. Al-Badrany, M.S. Laparoscopic ovariectomy in standing donkeys by titanium clip and monopolar electrocautery. J. Anim. Vet. Adv. 2007, 6, 663-667.

21. Alford, C.; Hanson, R. Evaluation of a transvaginal laparoscopic natural orifice transluminal endoscopic surgery approach to the abdomen of mares. Vet. Surg. 2010, 39, 873-878. [CrossRef]

22. Allen, W.R.; Wilsher, S.; Morris, L.; Crowhurst, J.S. Laparoscopic application of $\mathrm{PGE}_{2}$ to re-establish oviducal patency and fertility in infertile mares: A preliminary study. Equine Vet. J. 2006, 38, 454-459. [CrossRef]

23. Alsafy, M.; Elkammar, M.; Kassem, M.M.; Elgendy, S. Laparoscopic anatomy of the abdomen and Laparoscopic ligating loops, electrocoagulation, and a novel modified electroligation ovariectomy in standing mare. J. Am. Vet. Med. Assoc. 2013, 33, 912-923. [CrossRef]

24. Arnold, C.E.; Love, C.C. Laparoscopic evaluation of oviductal patency in the standing mare. Theriogenology 2013, 79, 905-910. [CrossRef]

25. Aziz, D.M.; Al-Badrany, M.S.; Taha, M.B. Laparoscopic ovariectomy in standing donkeys by using a new instrument. Anim. Reprod. Sci. 2008, 107, 107-114. [CrossRef] [PubMed]

26. Bartel, H.; Diekstall, M.; Shell, K.; Rijkenhuizen, A. Hand-assisted laparoscopic partial ovariohysterectomy in a standing mare suffering from a bleeding uterine leiomyoma. Pferdeheilkunde-Equine Med. 2020, 36, 495-501. [CrossRef]

27. Bracamonte, J.L.; Thoomas, K.L. Laparoscopic cryptorchidectomy with a vessel sealing device in dorsal recumbent horses: 43 Cases. Vet. Surg. 2017, 46, 559-565. [CrossRef] [PubMed]

28. Brink, P.; Schumacher, J.; Schumacher, J. Elevating the uterus (uteropexy) of five mares by laparoscopically imbricating the mesometrium. Equine Vet. J. 2010, 42, 675-679. [CrossRef] [PubMed]

29. Brommer, H.; Grinwis, G.C.M.; van Loon, V.; Ensink, J.M. Laparoscopic-assisted diagnosis of anomalous unilateral abdominal cryptorchidism. Equine Vet. Sci. 2011, 23, 391-395. [CrossRef]

30. Caron, J.P.; Brakenhoff, J. Intracorporeal Suture Closure of the Internal Inguinal and Vaginal Rings in Foals and Horses. Vet. Surg. 2008, 37, 126-131. [CrossRef] [PubMed] 
31. Carpenter, E.M.; Hendrickson, D.A.; James, S.; Frankie, C.; Frisbie, D.; Trostle, S.; Wilson, D. A Mechanical Study of Ligature Security of Commercially Available Pre-Tied Ligatures Versus Hand Tied Ligatures for Use in Equine Laparoscopy. Vet. Surg. 2006, 35, 55-59. [CrossRef]

32. Clements, P.E.; Coomer, R.P.C.; McKane, S.A.; Gorvy, D.; Bladon, B.; Mair, T. Clinical findings in 10 horses diagnosed with monorchidism following exploratory laparotomy or standing laparoscopic surgery. Equine Vet. Educ. 2019, 32, 431-436. [CrossRef]

33. Cockelaere, S.M.; Martens, A.M.J.G.; Wiemer, P. Laparoscopic ovariectomy in mares using a polyamide tie-rap. Vet. Surg. 2005, 34, 651-656. [CrossRef]

34. Cocklaere, S.M.; Martens, A.; Vanschandevijl, K.; Wilderjans, H.; Steenhaut, M. Hand-assisted laparoscopic nephrectomy after initial ureterocystostomy in a Shire filly with left ureteral ectopia. Vet. Rec. 2007, 161, 424-427. [CrossRef]

35. Colbath, A.C.; Hackett, E.S.; Lesser, C.S.; Hendrickson, D.A. Left paralumbar laparoscopic bilateral ovariectomy in mares. Vet. Surg. 2017, 46, 574-579. [CrossRef] [PubMed]

36. Collar, E.M.; Duesterdieck-Zellmer, K.F.; Huber, M.J.; Semevolos, S.A.; Parker, J.E.; Husby, K.A. Outcome of bilateral equid laparoscopic ovariectomies. Vet. Surg. 2021, 50, 975-983. [CrossRef] [PubMed]

37. Corsalini, J.; Gialletti, R.; Lotto, E.; Nannarone, S. Laparoscopic Uteropexy (Mesometrium Imbrication) in Three Mares Using a Barbed Suture. J. Equine Vet. Sci. 2016, 40, 102-105. [CrossRef]

38. Cribb, N.C.; Bouré, L. Laparoscopic removal of a large abdominal testicular teratoma in a standing horse. Vet. Surg. 2010, 39, 131-135. [CrossRef] [PubMed]

39. Cribb, N.C.; Koenig, J.; Sorge, U. Comparison of laparoscopic versus conventional open cryptorchidectomies on intraoperative and postoperative complications and duration of surgery, anesthesia, and hospital stay in horses. J. Am. Vet. Med. Assoc. 2015, 246, 885-892. [CrossRef] [PubMed]

40. Daniel, A.; McCue, P.; Ferris, R.; Miller, C.; Leise, B. Bilateral ovarian leiomyoma treated by standing laparoscopic ovariectomy. Equine Vet. Educ. 2015, 27, 510-514. [CrossRef]

41. Daniel, A.J.; Easley, J.T.; Story, M.R.; Hendrickson, D.A.; Hackett, E.S. Standing and assisted laparoscopic removal of large granulosa cell tumors in horses using a specimen retrieval bag and morcellator. Equine Vet. Educ. 2015, 27, 505-550. [CrossRef]

42. De Bont, M.P.; Wilderjans, H.; Simon, O. Standing Laparoscopic Ovariectomy Technique with Intraabdominal Dissection for Removal of Large Pathologic Ovaries in Mares. Vet. Surg. 2010, 39, 737-741. [CrossRef]

43. Delcazo, M.; Nieth, J.; Wehrend, A.; Röcken, M. Standing laparoscopic repair of a uterine rupture in a post-partum mare Pferdeheilkunde-Equine Med. 2020, 36, 299-305. [CrossRef]

44. Delcazo, M.; Pudert, T.; Al Naem, M.; Röcken, M. Laparoscopic two-steps ovariohysterectomy in five mares with chronic pyometra. Pferdeheilkunde-Equine Med. 2020, 36, 410-416. [CrossRef]

45. de Fourmestraux, C.; Geffroy, O.; Siliart, B.; Albaric, O.; Tessier, C. Evaluation of success rate of laparoscopic castration without orchidectomy in 32 mature horses. Equine Vet. Educ. 2014, 26, 34-39. [CrossRef]

46. Delling, U.; Howard, R.D.; Pleasant, R.; Lanz, O.I. Hand-Assisted Laparoscopic Ovariohysterectomy in the Mare. Vet. Surg. 2004, 33, 487-494. [CrossRef]

47. Desmaizieres, L.; Martinot, S.; Lepage, O.M.; Bareiss, E.; Cadoré, J.L. Complications Associated with Cannula Insertion Techniques Used for Laparoscopy in Standing Horses. Vet. Surg. 2003, 32, 501-506. [CrossRef] [PubMed]

48. Devick, I.F.; Leise, B.S.; Rao, S.; Hendrickson, D.A. Evaluation of post-operative pain after active desufflation at completion of laparoscopy in mares undergoing ovariectomy. Can. Vet. J. 2018, 59, 261-266. [PubMed]

49. Devick, I.F.; Hendrickson, D.A. Left paralumbar fossa approach combined with mesocolon fenestration for bilateral equine ovariectomy. Vet. Surg. 2019, 48, 735-741. [CrossRef] [PubMed]

50. Devick, A.F.; Leise, B.S.; McCue, P.M.; Rao, S.; Hendrickson, D.A. Ovarian histopathology, pre- and post-operative endocrinological analysis and behaviour alterations in 27 mares undergoing bilateral standing laparoscopic ovariectomy. Can. Vet. J. 2020, 61, 181-186.

51. Diekstall, M.; Rohde, C.; Rijkenhuizen, A.B.M. Post-partum uterine rupture: Standing repair in three mares using a laparoscopic technique. Equine Vet. Educ. 2018, 32, 319-324. [CrossRef]

52. Dusterdieck, K.F.; Pleasant, R.S.; Lanz, O.I.; Saunders, G.; Howard, R.D. Evaluation of the harmonic scalpel for laparoscopic bilateral ovariectomy in standing horses. Vet. Surg. 2003, 32, 242-250. [CrossRef]

53. Duersterdieck-Zellmer, K.F. Equine urolithiasis. Vet. Clin. Equine N. Am. Pract. 2007, 23, 613-629. [CrossRef]

54. Easley, J.T.; Hendrickson, D.A. Advances in laparoscopic techniques and instrumentation in standing equine surgery. Vet. Clin. N. Am Pract. 2014, 30, 19-44.

55. Easley, J.T.; McGilvray, K.C.; Hendrickson, D.A.; Bruemmer, J.; Hackett, E.S. Vessel sealer and divider instrument temperature during laparoscopic ovariectomy in horses. Vet. Surg. 2017, 47, O26-O31. [CrossRef]

56. El-Khamary, A.; El-Sherif, M. Laparoscopic castration in stallion with two different testicular blood vessels occluding techniques. J. Hell. Vet. Med. Soc. 2019, 70, 1429-1434. [CrossRef]

57. Farstvedt, E.G.; Hendrickson, D.A. Intraoperative pain responses following intraovarian versus mesovarian injection of lidocaine in mares undergoing laparoscopic ovariectomy. J. Am. Vet. Med. Assoc. 2005, 227, 593-596. [CrossRef]

58. Finley, C.J.; Fischer Jr, A.T. Removal of equine cryptorchid testes through an enlarged umbilical portal in dorsally recumbent horses after intra-abdominal laparoscopic castration. Equine Vet. J. 2021. [CrossRef] [PubMed] 
59. Gablehouse, K.B.; Cary, J.; Farnsworth, K.; Ragle, C.A. Standing laparoscopic-assisted vaginal ovariohysterectomy in a mare. Equine Vet. Educ. 2009, 21, 303-306. [CrossRef]

60. Goodin, J.T.; Rodgerson, D.H.; Gomez, J.H. Standing Hand-Assisted Laparoscopic Ovariectomy in 65 Mares. Vet. Surg. 2011, 40, 90-92. [CrossRef]

61. Gracia-Calvo, L.A.; Ortega, C.; Ezquerra, J. Laparoscopic closure of the internal inguinal rings in horses: A literature review. J. Equine Vet. Sci. 2014, 34, 1149-1155. [CrossRef]

62. Gracia-Calvo, L.A.; Duque, J.; da Silva, C.B.; Ezquerra, J.; Ortega-Ferrusola, C. Testicular perfusion after standing laparoscopic peritoneal flap hernioplasty in stallions. Theriogenology 2015, 84, 797-804. [CrossRef] [PubMed]

63. Graham, S.; Freeman, D. Standing diagnostic and therapeutic equine abdominal surgery. Vet. Clin. Equine N. Am. Pract. 2014, 30, 143-168. [CrossRef]

64. Hand, R.; Rakestraw, P.; Taylor, T. Evaluation of a Vessel-Sealing Device for Use in Laparoscopic Ovariectomy in Mares. Vet. Surg. 2002, 31, 240-244. [CrossRef]

65. Hanrath, M.; Rodgerson, D. Laparoscopic Cryptorchidectomy Using Electrosurgical Instrumentation in Standing Horses. Vet. Surg. 2002, 31, 117-124. [CrossRef] [PubMed]

66. Hartman, R.; Hawkins, J.F.; Adams, S.B.; Moore, G.E.; Fessler, J.F. Cryptorchidectomy in equids: 604 cases (1977-2010). J. Am. Vet. Med. Assoc. 2015, 246, 777-784. [CrossRef] [PubMed]

67. Hendrickson, D.A. Laparoscopic cryptorchidectomy and ovariectomy in horses. Vet. Clin. Equine N. Am. Pract. 2006, 22, 777-798. [CrossRef] [PubMed]

68. Hendrickon, D.A. Complications of laparoscopic surgery. Vet. Clin. Equine N. Am. Pract. 2009, 24, 557-571. [CrossRef] [PubMed]

69. Hilton, H.G.; Aleman, M.; Peterson, T.S.; Whitcomb, M.B.; Galuppo, L.D. Hand-assisted laparoscopic nephrectomy in a standing horse for the management of renal cell carcinoma. Equine Vet. Educ. 2008, 20, 239-244. [CrossRef]

70. Holmes, J.M.; Nath, L.C.; Muurlink, M.A. Laparoscopic cauterization of the testicular arteries to manage haemoperitoneum in a gelding. Equine Vet. Educ. 2012, 25, 297-300. [CrossRef]

71. Van Hoogmoied, L.M.; Galuppo, L.D. Laparoscopic Ovariectomy Using the Endo-GIA Stapling Device and Endo-Catch Pouches and Evaluation of Analgesic Efficacy of Epidural Morphine Sulfate in 10 Mares. Vet. Surg. 2005, 34, 546-650.

72. Hubert, J.D.; Burba, D.J.; Moore, R.M. Evaluation of a Vessel-Sealing Device for Laparoscopic Granulosa Cell Tumor Removal in Standing Mares. Vet. Surg. 2006, 35, 324-329. [CrossRef]

73. Huppes, T.; Stout, T.A.; Ensink, J.M. Decision making for cryptorchid castration: A retrospective analysis of 280 cases. J. Equine Vet. Sci. 2016, 48, 73-81. [CrossRef]

74. Janicek, J.C.; Rodgerson, D.H.; Boone, B.L. Use of a hand-assisted laparoscopic technique for removal of a uterine leiomyoma in a standing mare. J. Am. Vet. Med. Assoc. 2004, 225, 911-914. [CrossRef]

75. Jones, A.R.E.; Ragle, C.A.; Huggons, N.A.; Tibary, A.A. Bilateral ovariectomy as a treatment for chronic pyometra in four horses Equine Vet. Educ. 2020, 32, e189-e193. [CrossRef]

76. Joyce, J. A review of laparoscopic cryptorchidectomy. J. Equine Vet. Sci. 2008, 28, 112-117. [CrossRef]

77. Joyce, J.; Hendrickson, D.A. Comparison of intraoperative pain responses following intratesticular or mesorchial injection of lidocaine in standing horses undergoing laparoscopic cryptorchidectomy. J. Am. Vet. Med. Assoc. 2006, 229, 1779-1783. [CrossRef] [PubMed]

78. Kadic, D.T.; Bonilla, A.G. A two-step ovariohysterectomy with unilateral left flank laparoscopic assistance in a Quarter Horse mare. Equine Vet. Educ. 2019, 32, e199-e202. [CrossRef]

79. Kelmer, G.; Kramer, J.; Miler, M.A. Laparoscopic-assisted diagnosis of monorchidism in a horse. Equine Vet. Educ. 2006, 18, 84-89. [CrossRef]

80. Keoughan, C.G.; Rodgerson, D.H.; Brown, M.P. Hand-Assisted Laparoscopic Left Nephrectomy in Standing Horses. Vet. Surg. 2003, 32, 206-212. [CrossRef]

81. Koch, D.W.; Easley, J.T.; Hatzel, J.N.; Nelson, B.B.; Hendrickson, D.A.; Bruemmer, J.; Hackett, E.S. Prospective randomized investigation of topical anesthesia during unilateral laparoscopic ovariectomy in horses. Vet. Surg. 2020, 49 (Suppl. S1), O54-O59. [CrossRef]

82. Kollmann, M.; Rotting, A.; Heberling, A.; Sieme, H. Laparoscopic techniques for investigating the equine oviduct. Equine Vet. J. 2011, 43, 106-111. [CrossRef]

83. Kummer, M.; Theiss, F.; Jackson, M.; Furst, A. Evaluation of a Motorized Morcellator for Laparoscopic Removal of GranulosaTheca Cell Tumors in Standing Mares. Vet. Surg. 2010, 39, 649-653. [CrossRef]

84. Lacitignola, L.; Imperante, A.; De Siena, R.; Acquafredda, C.; Trisciuzzi, R.; Stabile, M.; Confalonieri, E.; Crovace, A.M.; Staffieri, F. Wound retractor laparoscopic port system for standing laparoscopic cryptorchidectomy in the horse: A case report. J. Equine Vet. Sci. 2020, 92, 103-168. [CrossRef]

85. Leonardi, L.; Bertoletti, A.; Bellezza, E.; Pettinari, I.; Gialletti, R. Dentigerous Equine Teratoma in a Stallion: Surgical Management and Clinicopathology. Vet. Sci. 2021, 8, 84. [CrossRef]

86. Lloyd, D.; Walmsley, J.P.; Greet, T.R.C.; Payne, R.J.; Newton, J.R.; Phillips, T.J. Electrosurgery as the sole means of haemostasis during laparoscopic removal of pathologic ally enlarged ovaries in mares: A report of 55 cases. Equine Vet. J. 2007, 39, 210-214. [CrossRef] [PubMed]

87. Loesch, D.A.; Rodgerson, D.H. Surgical approaches to ovariectomy in mares. Compendium 2003, 25, 862-870. 
88. Lund, C.M.; Ragle, C.A.; Lutter, J.D. Laparoscopic removal of a bladder urolith in a standing horse. J. Am. Vet. Med. Assoc. 2013, 243, 1323-1328. [CrossRef]

89. Lund, C.M.; Ragle, C.A.; Lutter, J.D.; Farnsworth, K.D. Use of a motorized morcellator for elective bilateral laparoscopic ovariectomy in standing equids: 30 cases (2007-2013). J. Am. Vet. Med. Assoc. 2014, 244, 1191-1197. [CrossRef] [PubMed]

90. Marien, T. Standing laparoscopic herniorraphy in stallions using a cylindrical polypropylene mesh prosthesis. Equine Vet. J. 2001, 33, 91-96. [CrossRef] [PubMed]

91. Major, D.S.; Duff, A.H.; Cohen, N.D.; Hardy, J. Ex vivo comparison of single-layer and double-layer laparoscopic closure of equine bladders with 2 types of barbed sutures. Vet. Surg. 2017, 46, 1145-1153. [CrossRef] [PubMed]

92. McNally, T.P.; Rodgerson, D.H.; Lu, K.G. Infertility in a mare with a chronic uterine tear, diagnosis and successful standing hand-assisted laparoscopic repair. Equine Vet. Educ. 2012, 24, 439-443. [CrossRef]

93. Merchan, A.; Barrett, E.J.; Rodgerson, D.H. Hand-assisted laparoscopic cystotomy for cystic calculus removal in male horses (3 cases). Can. Vet. J. 2021, 62, 22-26.

94. Muurlink, T.; Walmsley, J.; Whitton, C. Successful laparoscopic surgery for a uterine leiomyoma in a mare. Equine Vet. Educ. 2008, 20, 508-511. [CrossRef]

95. Oreff, G.L.; Tatz, A.J.; Ranen, E.; Dahan, R.; Kelmer, G. Laparoscopic-assisted tube cystotomy for urethral rupture in a foal. Equine Vet. Educ. 2015, 28, 690-695. [CrossRef]

96. Pader, K.; Lescun, T.B.; Freeman, L.J. Standing ovariectomy in mares using a transvaginal natural orifice transluminal endoscopic surgery (NOTES) approach. Vet. Surg. 2011, 40, 987-997. [CrossRef] [PubMed]

97. Pader, K.; Freeman, L.J.; Constable, P.D.; Wu, C.C.; Snyder, P.W.; Lescun, T.B. Comparison of Transvaginal Natural Orifice Transluminal Endoscopic Surgery (NOTES) and Laparoscopy for Elective Bilateral Ovariectomy in Standing Mares. Vet. Surg. 2011, 40, 998-1008. [CrossRef] [PubMed]

98. Peer, M.; Neuhauser, S.; Klaus, C.; Kuiper, H.; Gruber, A.D.; Distl, O.; Lischer, C.; Handler, J. Laparoscopic gonadectomy in two intersex warmblood horses. J. Equine Vet. Sci. 2012, 32, 117-122. [CrossRef]

99. Pepe, M.; Gialletti, R.; Moriconi, F.; Puccetti, M.; Nannarone, S.; Ringer, E.R. Laparoscopic Sterilization of Sardinia Donkeys Using an Endoscopic Stapler. Vet. Surg. 2005, 32, 260-264. [CrossRef]

100. Petrizzi, L.; Guerri, G.; Straticò, P.; Cuomo, A.; Vullo, C.; De Amicis, I.; Robbe, D.; Varasano, V. Laparoscopic Ovariectomy in standing mule mare. J. Equine Vet. Sci. 2020, 84, 102857. [CrossRef]

101. Pye, J.; Clulow, J.; Adkins, A. Laparoscopic transection of restrictive bands of the mesosalpinx as adjunct to the use of prostaglandin $\mathrm{E}_{2}$ for mares with suspected uterine tubal blockage. Aust. Vet. J. 2018, 96, 252-256. [CrossRef]

102. Quéré, E.; Bourzac, C.; Farfan, M.; Losada, A.; Volmer, C.; Mespoules-Rivière, C. Standing Hand-Assisted Laparoscopic Diagnosis and Treatment of a Rare Case of Uterine Adenocarcinoma in an 18-Year-Old Mare. J. Equine Vet. Sci. 2019, 79, 39-44. [CrossRef]

103. Ragle, C.A.; Yiannikouris, S.; Tibary, A.A.; Fransson, B.A. Use of a barbed suture for laparoscopic closure of the internal inguinal rings in a horse. J. Am. Vet. Med. Assoc. 2013, 242, 249-253. [CrossRef]

104. Rambags, B.P.B.; Stout, T.A.E.; Rijkenhuizen, A.B.M. Ovarian granulosa cell tumors adherent to other abdominal organs: Surgical removal from 2 warmblood mares. Equine Vet. J. 2003, 35, 627-632. [CrossRef]

105. Randleff-Rasmussern, P.K.; Gray, A.S. Metallic foreign body in the ovary of a broodmare. Equine Vet. Educ. 2016, 30, 237-240. [CrossRef]

106. Rijkenhuizen, A.B.M. Treatment of haemorrhage after castration by laparoscopic ligation of the spermatic cord in two horses. Pferdehelkunde 2002, 18, 339-342. [CrossRef]

107. Rijkenhuizen, A.B.M.; van Dijk, P. Diagnostic and therapeutic laparoscopy in the horse: Experience in 236 cases. Pferdehelkunde 2002, 18, 12-20. [CrossRef]

108. Rijkenhuizen, A.M.; Goehring, L. Laparoscopic repair of a bladder rupture in 2 foals. Pferdeheilkunde 2003, 19, 9-15. [CrossRef]

109. Rijkenhuizen, A.M.; van Loon, T.J.A.M.; Boswinkel, M. Laparoscopic repair of a ruptured bladder in an adult mare. Equine Vet. Educ. 2008, 20, 183-189. [CrossRef]

110. Rijkenhuizen, A.B.M.; van der Harst, M. Castration in the standing horse combining laparoscopic and conventional technique. Equine Vet. J. 2017, 49, 776-779. [CrossRef]

111. Rijkenhuizen, A.B.M.; Lichtennberg, D.; Weitkamp, K. Cystic intra-abdominal testicles: Standing laparoscopic removal in two colts. Equine Vet. Educ. 2018, 32, e130-e135. [CrossRef]

112. Rijenhuizen, A.B.M.; Jonker, F.H.; Grinwis, G. Efficacy of laparoscopic ligation of the mesovarium of the mare in the standing position without removal of the ovary. Pferdehelkunde-Equine Med. 2021, 37, 9-17. [CrossRef]

113. Rocken, M.; Stehle, C.; Mosel, G.; Rass, J.; Litzke, L.F. Laparoscopic-Assisted Cystotomy for Urolith Removal in Geldings. Vet. Surg. 2006, 35, 395-397. [CrossRef]

114. Rocken, M.; Mosel, G.; Stehle, C.; Rass, J.; Litzke, L.F. Left- and Right-Sided Laparoscopic-Assisted Nephrectomy in Standing Horses with Unilateral Renal Disease. Vet. Surg. 2007, 36, 568-572. [CrossRef]

115. Rocken, M.; Mosel, G.; Seyrek-Intas, K.; Seyrek-Intas, D.; Litzke, L.F.; Verver, J.; Rijkenhuizen, A.B.M. Unilateral and Bilateral Laparoscopic Ovariectomy in 157 Mares: A Retrospective Multicenter Study. Vet. Surg. 2011, 40, 1009-1014. [CrossRef] [PubMed]

116. Rodgerson, D.H.; Belknap, J.K.; Wilson, D.A. Laparoscopic Ovariectomy Using Sequential Electrocoagulation and Sharp Transection of the Equine Mesovarium. Vet. Surg. 2001, 30, 572-579. [CrossRef] [PubMed] 
117. Rodgerson, D.H.; Brown, M.P.; Watt, B.C.; Keoughan, C.G.; Hanrath, M. Hand-assisted laparoscopic technique for removal of ovarian tumors in standing mares. J. Am. Vet. Med. Assoc. 2002, 220, 1503-1507. [CrossRef] [PubMed]

118. Roessner, H.A.; Kurtz, K.A.; Caron, J.P. Laparoscopic Ovariectomy Diminishes Estrus-Associated Behavioural Problems in Mares. J. Equine Vet. Sci. 2015, 35, 250-253. [CrossRef]

119. Romero, A.; Rodgerson, D.H.; Fontaine, G. Hand-assisted laparoscopic removal of a nephroblastoma in a horse. Can. Vet. J. 2010, 51, 637-639.

120. Rossignol, F.; Perrin, R.; Boening, K.J. Laparoscopic Hernioplasty in Recumbent Horses Using Transposition of a Peritoneal Flap. Vet. Surg. 2007, 37, 557-562. [CrossRef]

121. Rossignol, F.; Mespoulhes-Rivière, C.; Vitte, A.; Lechartier, A.; Boening, K.J. Standing Laparoscopic Inguinal Hernioplasty Using Cyanoacrylate for Preventing Recurrence of Acquired Strangulated Inguinal Herniation in 10 Stallions. Vet. Surg. 2014, 43, 6-11. [CrossRef]

122. Rubiomartinez, L.M. Standing laparoscopic castration in an equine male pseudohermaphrodite. Equine Vet. Educ. 2011, 24, 507-510. [CrossRef]

123. Ruzickova, P.; Burns, P.; Piat, P.; Frasch, M.; Beauchamp, G.; Elce, Y.A. Ex Vivo Biomechanical Comparison of 4 Suture Materials for Laparoscopic Bladder Closure in the Horse. Vet. Surg. 2016, 45, 374-379. [CrossRef]

124. Sassot, L.N.; Ragle, C.A.; Farnsworth, K.D.; Lund, C.M. Morcellation for testes extraction in horses undergoing standing laparoscopic cryptorchidectomy. Can. Vet. J. 2017, 58, 1215-1220.

125. Shoemaker, R.W.; Read, E.K.; Duke, T.; Wilson, D.G. In situ coagulation and transection of the ovarian pedicle: An alternative to laparoscopic ovariectomy in juvenile horses. Can. J. Vet. Res. 2004, 68, 27-32. [PubMed]

126. Seabaugh, K.A.; Goodrich, L.R.; Morley, P.S.; Bohn, A.; Rao, S.; Hendrickson, D.A. Comparison of Peritoneal Fluid Values after Laparoscopic Cryptorchidectomy using a Vessel Sealing Device (LigasureTM) Versus a Ligating Loop and Removal of the Descended Testis. Vet. Surg. 2013, 42, 600-606. [CrossRef] [PubMed]

127. Seabaugh, K.A.; Schumacher, J. Urogenital surgery performed with the mare standing. Vet. Clin. Equine Equine Pract. 2014, 30, 191-209. [CrossRef] [PubMed]

128. Seabaugh, K.A.; Goodrich, L.R.; Bohn, A.; Morley, P.S.; Hendrickson, D.A. A comparison of peritoneal fluid values in mares following bilateral laparoscopic ovariectomy using a vessel sealing and dividing device versus placement of two ligating loops. Vet. J. 2014, 202, 297-302. [CrossRef] [PubMed]

129. Silva, L.C.; Zoppa, A.L.V.; Hendrickson, D.A. Equine diagnostic laparoscopy. J. Equine Vet. Sci. 2008, 28, 2247-2254. [CrossRef]

130. Smith, C.L.; Dowling, B.A.; Dart, A.J. Recent adavances in equine abdominal surgery. Vet. J. 2005, 170, 41-45. [CrossRef]

131. Smith, L.J.; Mair, T.S. Unilateral and bilateral laparoscopic ovariectomy of mares by electrocautery. Vet. Rec. 2008, 163, 297-300. [CrossRef]

132. Smith, L.J.; Perkins, J.D. Laparoscopic-assisted castration of a monorchid male pseuodohermaphrodite pony. Equine Vet. Educ. 2009, 21, 295-299. [CrossRef]

133. Smith, S.E.; Devine, D.V. Hand-Assisted Laparoscopic Ovariectomy and Colpotomy in Standing Mares. Vet. Surg. 2013, 42, 586-590. [CrossRef]

134. Straticò, P.; Suriano, R.; Sciarrini, C.; Varasano, V.; Petrizzi, L. Laparoscopic-Assisted Cystotomy and Cystostomy for Treatment of Cystic Calculus in a Gelding. Vet. Surg. 2012, 41, 634-637. [CrossRef]

135. Straticò, P.; Varasano, V.; Guerri, G.; Celani, G.; Palozzo, A.; Petrizzi, L. A Retrospective Study of Cryptorchidectomy in Horses: Diagnosis, Treatment, Outcome and Complications in 70 Cases. Animals 2020, 10, 2446. [CrossRef] [PubMed]

136. Tate, L.P.; Fogle, C.A.; Bailey, C.S.; Tate, K.B.; Davis, J.W. Laparoscopic-Assisted Colpotomy for Ovariectomy in the Mare. Vet. Surg. 2012, 41, 625-628. [CrossRef] [PubMed]

137. Tuohy, J.L.; Hendrickson, D.A.; Hendrix, S.M.; Bohanon, T.C. Standing laparoscopic repair of a ruptured urinary bladder in a mature draught horse. Equine Vet. Educ. 2009, 21, 257-261. [CrossRef]

138. Vanhaesebrouck, E.; Govaere, J.; Smits, K.; Durie, I.; Vercauteren, G.; Martens, A.; Schauvliege, S.; Ducatelle, R.; Hoogewijs, M.; De Schauwer, C.; et al. Ovarian teratoma in the mare: A review and two cases. Vlaams Diergeneeskyndig Tijdschr. 2010, 10, 32-41.

139. Velez, I.C.; Arnold, C.; Jacobson, C.C.; Norris, J.D.; Choi, Y.H.; Edwards, J.F.; Hayden, S.S.; Hinrichs, K. Effects of repeated transvaginal aspiration of immature follicles on mare health and ovarian status. Equine Vet. J. 2012, 4, 78-83. [CrossRef]

140. Vitoria, A.; Romero, A.; Fuente, S.; Barrachina, L.; Vazquez, F.J. Application of a laparoscopic technique for vasectomy in standing horses. Vet. Rec. 2019, 185, 345. [CrossRef]

141. Vitte, A.; Mespoulhes-Rivière, C.; Lechartier, A.; Rossignol, F. Removal of cystic calculi using a transinguinal laparoscopic-assisted technique in two stallions. Equine Vet. Educ. 2013, 25, 573-577. [CrossRef]

142. Vitte, E.; Rossignol, F.; Mespoulhes-Rivière, C.; Lechartier, A.; Roecken, M. Two-Step Surgery Combining Standing Laparoscopy with Recumbent Ventral Median Celiotomy for Removal of Enlarged Pathologic Ovaries in 20 Mares. Vet. Surg. 2014, 43, 663-667. [CrossRef]

143. Voermans, M.; Rijkenhuizen, A.B.M.; van der Velden, M.A. The complex blood supply to the equine testis as a cause of failure in laparoscopic castration. Equine Vet. J. 2006, 38, 35-39. [CrossRef]

144. Waguespack, R.; Belknap, J.; Williams, A. Laparoscopic management of post castration haemorrhage in a horse. Equine Vet. J. 2001, 33, 510-513. [CrossRef] 
145. Walesby, H.A.; Ragle, C.A.; Booth, L.C. Laparoscopic repair of ruptured urinary bladder in a stallion. J. Am. Vet. Med. Assoc. 2002, 221, 1737-1741. [CrossRef] [PubMed]

146. Wilderjans, H.; Meulyzer, M.; Simon, O. Standing Laparoscopic Peritoneal Flap Hernioplasty Technique for Preventing Recurrence of Acquired Strangulating Inguinal Herniation in Stallions. Vet. Surg. 2012, 41, 292-299. [CrossRef] [PubMed]

147. Wilderjans, H.; Meulyzer, M. Laparoscopic closure of the vaginal ring in the standing horse using a tacked intraperitoneal slitted mesh (TISM) technique. Equine Vet. J. 2021, 1-9. [CrossRef] [PubMed]

148. Woodford, N.S.; Payne, R.J.; McCluskie, L.K. Laparoscopically-assisted ovariohysterectomy in three mares with pyometra. Equine Vet. Educ. 2014, 26, 75-78. [CrossRef]

149. Hayden, J.A.; van der Windt, D.; Cartwright, J.L.; Coté, P.; Bombardier, C. Assessing bias in studies of prognostic factors. Ann. Intern. Med. 2013, 158, 280-286. [CrossRef]

150. Boure, L.; Marcoux, M.; Laverty, S. Paralumbar fossa laparoscopic ovariectomy in horses with use of Endoloop ligatures. Vet. Surg. 1997, 26, 478-483. [CrossRef]

151. Kalloo, A.N.; Singh, V.K.; Jagannath, S.B.; Niiyama, H.; Hill, S.L.; Vaughn, C.A.; Magee, C.A.; Kantsevoy, S.V. Flexible transgastric peritoneoscopy: A novel approach to diagnostic and therapeutic interventions in the peritoneal cavity. Gastrointest. Endosc. 2004, 60, 114-117. [CrossRef]

152. Onders, R.P.; McGee, M.F.; Marks, J.; Chak, A.; Rosen, M.J.; Ignagni, A.; Faulx, A.; Schomisch, S.; Ponsky, J. Natural orifice transluminal endoscopic surgery (NOTES) as a diagnostic tool in the intensive care unit. Surg. Endosc. 2007, 21, 681-683. [CrossRef]

153. Wallace, M.B. Take NOTES (natural orifice transluminal endoscopic surgery). Gastroenterology 2006, 131, 11-12. [CrossRef]

154. Hussain, A.; Mahmood, H. NOTES: Current status and expectations. Eur. Surg. 2008, 4, 176-186. [CrossRef]

155. Embertson, R.M. Ovaries and uterus. In Equine Surgery, 3rd ed.; Auer, J.A., Stick, J.A., Eds.; W.B. Saunders: St. Louis, MO, USA, 2006; pp. 855-864.

156. Walker, D.F.; Vaughan, J.T. Surgery of the ovaries and adnexa. In Bovine and Equine Urogenital Surgery; Walker, D.F., Vaughan, J.T., Eds.; Lea \& Febiger: Philadelphia, PA, USA, 1980; pp. 241-253.

157. Colbern, G.T.; Reagan, W.J. Ovariectomy by colpotomy in mares. Compend. Contin. Educ. Pract. Vet. 1987, 9, 1035-1038.

158. Rodgerson, D.H. Hand-assisted laparoscopy. In Advances in Equine Laparoscopy; Ragle, C.A., Ed.; Wiley \& Sons, Inc.: Hoboken, NJ, USA, 2012; pp. 324-329.

159. Ragle, C. Laparoscopic removal of cystic calculi. In Equine Diagnostic and Surgical Laparoscopy; Fischer, A.T., Ed.; Saunders: Philadelphia, PA, USA, 2002; pp. 229-234.

160. Beard, W.L. Parainguinal laparocystotomy for urolith removal in geldings. Vet. Surg. 2004, 33, 386-390. [CrossRef]

161. Lowe, J. Long-term results of cystotomy removal of uroliths from horses. J. Am. Vet. Med. Assoc. 1965, 147, 147. [PubMed]

162. Manganiello, M.; Kenney, P.; Canes, D.; Sorcini, A.; Moinzadeh, A. Unidirectional barbed suture versus standard monofilament for urethrovescical anastomosis during robotic assisted laparoscopic radical prostatectomy. Int. Braz. J. Urol. 2012, 38, 89-96. [CrossRef] [PubMed]

163. Shah, H.N.; Nayyar, R.; Rajamahanty, S.; Hemal, A.K. Prospective evaluation of unidirectional barbed suture for various indications in surgeon-controlled robotic reconstructive urologic surgery: Wake Forest University experience. Int. Urol. Nephrol. 2012, 44, 775-785. [CrossRef]

164. Massoud, W.; Thanigasalam, R.; El Hajj, A.; Girard, F.; Theveniaud, P.E.; Chatellier, J.; Baumert, H. Does the use of a barbed polyglyconate absorbable suture have an impact on urethral anastomosis time, urethral stenosis rates, and cost effectiveness during robot-assisted radical prostatectomy? Urology 2013, 82, 90-94. [CrossRef] [PubMed]

165. Spah, C.E.; Elkins, A.D.; Wehrenberg, A.; Jaffe, M.H.; Baird, D.K.; Naughton, J.F.; Payton, M.E. Evaluation of two novel selfanchoring barbed sutures in a prophylactic laparoscopic gastropexy compared with intracorporeal tied knots. Vet. Surg. 2013, 42, 932-942. [CrossRef]

166. Albanese, V.; Hanson, R.R.; McMaster, M.A.; Koehler, J.W.; Caldwell, F.J. Use of a Barbed Knotless Suture for Laparoscopic Ablation of the Nephrosplenic Space in 8 Horses. Vet. Surg. 2016, 45, 824-830. [CrossRef]

167. van Dijk, P.; Lankveld, D.P.K.; Rijkenhuizen, A.B.M.; Jonker, F.H. Hormonal, metabolic, and physiological effects of laparoscopic surgery using a detomidine-buprenorphine combination in standing horses. Vet. Anaesth. Analg. 2003, 30, 71-79. [CrossRef]

168. Solano, A.M.; Valverde, A.; Desrochers, A.; Nykamp, S.; Boure, L.P. Behavioral and cardiorespiratory effects of a constant rate infusion of medetomidine and morphine for sedation during standing laparoscopy in horses. Equine Vet. J. 2009, 41, 153-159. [CrossRef]

169. Martin-Flores, M.; Campoy, L.; Kinsley, M.A.; Mohammed, H.O.; Gleed, R.D.; Cheetham, J. Analgesic and gastrointestinal effects of epidural morphine in horses after laparoscopic cryptorchidectomy under general anaesthesia. Vet. Anaesth. Analg. 2014, 41, 430-437. [CrossRef] [PubMed]

170. Kim, A.; Sasaki, N.; Lee, I.; Seo, J. Comparison of intraoperative cardiorespiratory and behavioral responses to medetomidine combined with tramadol or butorphanol during standing laparoscopic ovariectomy in horses. J. Vet. Med. Sci. 2021, 83, 643-647. [CrossRef] [PubMed]

171. Lawless, S.P.; Moorman, V.J.; Hendrickson, D.A.; Mama, K.R. Comparison of sedation quality and safety of detomidine and romifidine as a continuous rate infusion for standing elective laparoscopic ovariectomy in mares. Vet. Surg. 2021, 50, 990-998. [CrossRef] [PubMed] 
172. Vullo, C.; Tambella, A.M.; Meligrana, M.; Catone, G. Analgesic and Sedative Effects of Epidural Lidocaine-Xylazine in Elective Bilateral Laparoscopic Ovariectomy in Standing Mule Mares. Animals 2021, 11, 2419. [CrossRef] [PubMed]

173. Skarda, R.T.; Grosenbaugh, D.A.; Muir, W.W. Caudal regional anaesthesia in horses. Equine Vet. Educ. 2005, 7, 108-116. [CrossRef]

174. Natalini, C.C. Spinal anesthetics and analgesics in the horse. Vet. Clin. N. Am. Equine Pract. 2010, 26, 551-564. [CrossRef] [PubMed]

175. Vigani, A.; Garcia-Pereira, F.L. Anesthesia and analgesia for standing equine surgery. Vet. Clin. N. Am. Equine Pract. 2014, 30, 1-17. [CrossRef]

176. Natalini, C.C.; Driesen, B. Epidural and spinal anesthesia and analgesia in the equine. Clin. Techniq. Equine Pract. 2007, 6, 145-153. [CrossRef]

177. Sach, W.O.; Habel, R.E. Rooney's Guide to Dissection of the Horse; Veterinary Textbooks; Cornell University: Ithaca, NY, USA, 1977; Volume 48, p. 63. ISBN 0960115218.

178. Hofmeister, E.; Peroni, J.F.; Fischer, A.T., Jr. Effects of Carbon Dioxide Insufflation and Body Position on Blood Gas Values in Horses Anesthetized for Laparoscopy. J. Equine Vet. Sci. 2008, 28, 549-553. [CrossRef]

179. Canola, P.A.; Perotta, J.H.; Laskoski, L.M.; Escobar, A.; Melo e Silva, C.A.; Canola, J.C.; Johnson, P.J.; Valadao, C.A.A. Effect of passive pneumoperitoneum on oesophageal pressure, cardiovascular parameters and blood gas analysis in horses. Equine Vet. J. 2011, 43, 446-450. [CrossRef]

180. Munsterman, A.S.; Gillen, A.M.; Coleridge, M.O.; Hanson, R.R. Evaluation of the effects of medial saphenous venous pressures as an indirect method of measurement of intra-abdominal pressures in the horse. J. Vet. Emerg. Crit. Care 2020, 30, 660-669. [CrossRef] [PubMed] 